\title{
Digital Rights During the Covid-19 Pandemic in Latin America
}

\author{
María Soledad Segura \\ Consejo Nacional de Investigaciones Científicas y Técnicas, Argentina/Facultad de Ciencias Sociales y \\ Facultad de Ciencias de la Comunicación, Universidad Nacional de Córdoba, Córdoba, Argentina
}

\section{Ana Bizberge}

Instituto de Estudios de América Latina y el Caribe, Facultad de Ciencias

Sociales, Universidad de Buenos Aires, Buenos Aires, Argentina

\begin{abstract}
This article discusses digital rights during covid-19 pandemic. It offers a comparative analysis of the measures that affected digital rights to freedom of expression, access and privacy implemented by governments and private companies (internet service providers and internet intermediaries) between March and August 2020 in Argentina, Brazil and Mexico. It also studies reactions from civil society and international organizations. The theoretical framework draws on human rights provisions about progressive and regressive policy making. The central questions are: how are digital rights of freedom of expression, access and privacy affected by companies and governments during the period under consideration in the three countries studied? How have civil society organizations and international organizations position themselves with regards to these digital rights? It is based on a comparative analysis of how government, private sector, and civil society stakeholders have responded to the information and communications technology governance challenges created by the pandemic, and how their governance responses have impacted human rights in the areas of freedom of expression, access, and privacy. Answering these questions is relevant to identify and understand the precedent that these strategies developed in an exceptional context - could set for the post-crisis scenario, which exceeds the scope of this article. Conclusions show that public policies adopted during covid-19 varied in the three countries. However, in the three, both progressive and regressive measures can be identified. The companies developed regressive strategies, implemented some progressive but exceptional measures; while civil society and international organizations promoted progressive and long-term solutions.
\end{abstract}

\section{Direitos Digitais Durante a Pandemia DE Covid-19 NA AmÉrica LATINA}

\begin{abstract}
RESUMO
Este artigo discute os direitos digitais durante a pandemia de covid-19. Propõe uma análise comparativa das medidas que afetaram os direitos digitais à liberdade de expressão, acesso e privacidade implementadas por governos e empresas privadas (fornecedores de serviço de internet e intermediários de internet) entre março e agosto de 2020 na Argentina, Brasil e México.
\end{abstract}




\begin{abstract}
Também estuda reações da sociedade civil e de organizações internacionais. A estrutura teórica baseia-se em disposições de direitos humanos sobre a formulação de políticas progressivas e regressivas. As questões centrais são: como os direitos digitais de liberdade de expressão, acesso e privacidade foram afetados por empresas e governos durante o período considerado nos três países estudados? Como as organizações da sociedade civil e as organizações internacionais se posicionam em relação a esses direitos digitais? É baseado em uma análise comparativa de como o governo, o setor privado e as partes interessadas da sociedade civil responderam aos desafios de governança de tecnologias da informação e comunicação criados pela pandemia, e como suas respostas de governança impactaram os direitos humanos nas áreas de liberdade de expressão, acesso e privacidade. Responder a estas questões é relevante para identificar e compreender o precedente que estas estratégias - desenvolvidas num contexto excepcional - podem abrir para o cenário pós-crise, que extrapola o âmbito deste artigo. As conclusões mostram que as políticas públicas adotadas durante a covid-19 variaram nos três países. No entanto, tanto medidas progressivas quanto regressivas podem ser identificadas nos três. As empresas desenvolveram estratégias regressivas, implementaram também algumas medidas progressivas, mas excepcionais; enquanto a sociedade civil e as organizações internacionais promoveram soluções progressivas e de longo prazo.
\end{abstract}

\title{
Palavras-chave
}

direitos digitais, internet, covid-19, confinamento, América Latina

\section{INTRODUCTION}

The new needs and problems posed by the advance of the first global pandemic of coronavirus (covid-19) and the exceptional measures of isolation of the population adopted in many countries of the world have reignited public debates on digital rights. Besides, they have moved from the narrow circle of specialists to the broader realm of social, media and political discussion. These new challenges go beyond national borders as a result of the scope of the virus circulation and of the policies adopted to face it, as well as of the global structure of the internet network and the transnational nature of the service providers. However, they have taken on specific features in each region and country.

This paper analyzes strategies, debates and disputes about digital rights during the advance of the pandemic and the various measures of isolation taken in Mexico, Argentina, and Brazil. The timeframe under analysis is March 13, 2020, - the date when Uruguay established a quarantine, the first country in the region to do so - until August 31,2020 , the closing date of this article. The central questions are: how are digital rights of freedom of expression, access and privacy affected by companies and governments during the period under consideration in the three countries studied? How have civil society organizations and international organizations position themselves with regards to these digital rights? In other words, this is a review of information and communication technology (ICT) policymaking in the face of the covid-19 pandemic. It is based on a comparative analysis of how government, private sector, and civil society stakeholders have responded to the ICT governance challenges created by the pandemic, and how their governance responses have impacted human rights in the areas of freedom of expression, access, and privacy. It presents the policy dilemmas and its stakeholders' 
responses in the region. Answering these questions is relevant to identify and understand the precedent that these strategies - developed in an exceptional context - could set for the post-crisis scenario, which exceeds the scope of this article.

These questions are approached from the theoretical perspective of communication as a fundamental human right, as well as from the approach of communication policies as the field of disputes of meanings within a certain configuration of the relationships of social forces. The methodological approach is a theoretical-normative comparative analysis on the progression or regression of the measures adopted as regards human rights.

The argument is that the debate dealing with the internet during the pandemic and isolation in Latin America involves three types of digital rights: access, privacy, and freedom of expression. Each of these rights is affected by various kinds of problems caused by the action of governments and/or internet companies: connectivity, critical content for a fee, patient geolocation, content removal, promotion of self-censorship, disinformation. State policies included regressive as well as progressive measures. Sometimes, the latter were adopted in association with civil society. At a global level, companies developed regressive strategies which they had to reverse in certain cases, and some progressive but exceptional measures, while the civil society in each country and multilateral organizations promoted progressive and long-term solutions.

First, the theoretical and methodological approach is presented. Then, the strategies and disputes that developed around digital rights to freedom of expression, access and privacy in each country are comparatively analyzed. Finally, conclusions are offered.

\section{Theoretical and Methodological Approach}

In order to account for the process of developing and implementing policies in the context of a health emergency, public policy is understood as the response of the state either by action or by omission - to a problem that takes on a public dimension (Oszlak \& O'Donnell, 1976). Therefore, it implies disputes of meanings within a certain configuration of power relationships (Castells, 2009). In particular, communication policies refer to the setting of general goals for the organization of the media system through regulation (either formal, such as laws or administrative acts, or informal, such as voluntary agreements), which develops from the interaction of different types of actors who use formal and informal mechanisms to influence the configuration of the sector (Freedman, 2008; McQuail, 2010). With regard to the internet, the term "governance" — rather than policies - is increasingly used to highlight a change in the decision-making process: the shift from the classic decision-making process that places the state as a central actor to new forms of a regulatory and non-hierarchical structure where the actors involved make decisions as stakeholders as legitimately as other actors, and take on the role of regulators together with those regulated (Iosifidis, 2011).

Thus, for the study of the policies that affect the exercise of digital rights, it is important to analyze not only the behavior of the states in the region, but also the social 
discussion of these issues, the positioning of civil society organizations, and the actions of companies, especially internet intermediaries as enablers or inhibitors of the exercise of rights online.

Civil society is not a unified whole; it is complex, conflictive, and heterogeneous. It is not a homogeneous or pure sphere, a seat of freedom facing state oppression, and of altruism facing market domination. On the contrary, it has a relatively autonomous relationship with both state and market (Sorj, 2010). In particular, digital rights activism is a form of collective action that promotes more egalitarian access and management of technology and data, engages in new forms of information and knowledge production, and questions dominant concepts on digitization of information and connectivity (Milan \& van der Velden, 2016).

Meanwhile, large digital platforms are currently contributing to the emergence of new forms of capture of public policies by elites (Schiffrin, 2017). This was also acknowledged by international organizations that have impact on the Latin American system: considering that the access and use of internet is a human right (Comisión Interamericana de Derechos Humanos, 2011, 2019a), they recognize its potential for the circulation of ideas but, at the same time, they warn about the challenges generated by internet intermediaries who, on account of their size and position, exercise "private control" over the access and circulation of content on the internet (Comisión Interamericana de Derechos Humanos, 2013, 2017, 2019a; Unesco, 2019; United Nations, 2018).

Digital rights imply the protection and realization of existing rights, such as the right to privacy, access to information, or freedom of expression in the context of new digital and connectivity technologies. They are the rights to access, use, create, and publish by digital means as well as access, use, manufacture, and manage electronic devices and telecommunications networks. In particular, the rights to freedom of expression and access to information on the internet take up the tradition of the human right to communication based on the principles of access, plurality, diversity, participation, and equity (International Commission for the Study of Communication Problems, 1980), which refer both to the access and use of digitization technologies and connectivity themselves and to the production, access and management of private and public data as well. The right to communicate includes and exceeds those to freedom of expression (no censorship or inducing self-censorship) and to access to public information. When such rights are applied to new technologies, they face new challenges that call for redefinition, clarification, and extension. One of them is the principle of net neutrality, according to which all content that circulates on the internet must receive the same treatment and cannot be discriminated against based on its origin, use or application ( $\mathrm{Wu}, 2003)$. Free access - as long as there is acknowledgment of copyright compatible with free access and the kind of collaborative production that technology allows (Jenkins, 2006; Katzenbach, 2012; Lessig, 2004) are especially promoted. Civil rights to privacy are also retaken against the control of states and the use of private data for commercial purposes: digital surveillance is linked to the cost-free use of behavioral data, partly to improve products or services, but also to anticipate what people will do in the future (Zuboff, 2019). 
The definitions of "freedom of expression", "access" and "privacy" as human rights used here are those of multilateral organizations, specially the Organization of American States and United Nations. International human rights standards overcome the statist and mercantilist approaches, because they seek to curb both the power of the market and the state (Segura \& Waisbord, 2016).

The principle of progressiveness for the protection of human rights is enshrined in the American Convention on Human Rights (1969), in the Universal Declaration of Human Rights (1948), as well as in documents of the Inter-American Commission on Human Rights (Comisión Interamericana de Derechos Humanos) of the Organization of American States. This principle establishes that states must guarantee, at the national and international level, the exercise of the rights recognized in the Universal Declaration of Human Rights from 1948. The American Convention of Human Rights of 1969 (Article 26) and the Protocol of San Salvador (1988) link the progressiveness principle to economic, social, and cultural rights. These instruments point out that states must adopt measures to progressively achieve the effectiveness of these rights and account for it through periodic reports. For its part, the statute of creation of the Inter-American Commission on Human Rights establishes among its functions the formulation of recommendations to governments for the adoption of progressive measures in favor of human rights (Estatuto de la Comisión Interamericana de Derechos Humanos, 1979, Article 18.b.). Likewise, the commission set a series of guidelines for the elaboration of progress indicators in the area of economic, social and cultural rights that allow monitoring the application of public policies for the progressive realization of rights (Comisión Interamericana de Derechos Humanos, 2008). To sum up, the principle of progressiveness refers to the adoption of measures to promote the full exercise of human rights progressively and implies its opposite, non-regressiveness, which prevents states from adopting measures that worsen the situation of rights enjoyed by the population.

At the methodological level, a comparative analysis of the measures that affected digital rights implemented by governments and companies, and the positions and alternative developments of civil society and international organizations during the advance of the pandemic of covid-19 and the policies of isolation adopted between March and August 2020 in Argentina, Brazil and Mexico were carried out.

The comparative method is a qualitative approach that serves to study similarities and differences between a moderate number of cases - as proposed in this article for which in-depth knowledge of each one is important (Ragin, 1994/2007). Although formally case study and comparative methods are presented as distinctive approaches, there is consensus over their complementarity because their boundaries become blurry (George \& Bennett, 2004; Lijphart, 1971). The comparative approach allows the joint analysis of different cases and phenomena to find explanatory factors, explore diversity, interpret the cultural or historical relevance of an event, and advance the theory (Ragin, 1994/2007). Comparative studies help understand how parallel processes of change play out differently according to the context (Collier, 1993). Thus, the comparison proposed in this article is not limited to the description of similarities and differences in the measures 
adopted by different types of players in Argentina, Brazil, and Mexico, but also brings a framework of understanding to evaluate them based on the progressiveness/regressiveness of rights in accordance with international standards.

A widespread argument around comparative research is the need to consider a diversity of contexts or environments in which these complex objects are situated. Within the broad spectrum of comparative studies, we work on a specific variant, trans-contextual studies and, specifically, one of its two typical forms: cross-national studies. Crossnational research, although not free from philosophical and methodological problems, is facilitated because the modern idea of the nation-state, exported and imposed from western Europe, has been in a sense stabilized and consolidated globally. Beyond the criticisms that can be made about the circumstances in which these historical processes took place, it seems clear that there are certain properties that make states comparable to each other. In any case, it is necessary to take into account the current context of globalization in which the meaning of national states is in question and new configurations emerge between the national, the supranational, the transnational, the local, and the global (Piovani \& Krawczyk, 2017). In our work, this is observable in the tensions between the various multilateral, transnational, national, and local stakeholders.

The selection criteria for the cases under analysis are as follows:

- These are the countries with the largest territorial extension, the largest number of inhabitants (together with Colombia), and the largest nominal gross domestic product in Latin America. Therefore, they have relevant political and economic influence in the region (Organización para la Cooperación y el Desarrollo Económicos et al., 2019).

- Their governments have different political orientations: rightist in Brazil, progressive from traditional parties in Argentina and Mexico (Centro Estratégico Latinoamericano de Geopolítica, 2020).

- Their national governments' political communication strategies regarding the advance of the pandemic were different: in Argentina the problem was quickly acknowledged while in Brazil it was denied, and in Mexico it was initially minimized and then confronted (Centro Estratégico Latinoamericano de Geopolítica, 2020).

- The measures adopted to contain the spread of the virus include various levels of restriction: they have been very restrictive with mandatory isolation throughout the country in Argentina since March 20. In Brazil and Mexico, measures have been moderately restrictive: lockdowns are recommended at the national level and mandatory only in some states as from March 17 and 30, respectively (Coronavirus: El mapa interactivo que muestra las medidas o distintos tipos de cuarentena que adoptaron los países de América Latina, 2020).

- The states developed different strategies to address the new needs and problems connected with digital rights that emerged during the advance of the pandemic.

For the comparative analysis, a theoretical-normative approach to the implications — in terms of progression or regression of rights according with the international standards above mentioned - of public policies and business strategies adopted as well as of civil society and multilateral organizations positioning and alternative developments is carried out.

The analytical dimensions are: governments, private sector, civil society and alternative experiences and international organizations measures and positions that affected freedom of expression, access and privacy in Argentina, Brazil and Mexico during the 
covid-19 pandemic. The causal factors that explain the responses offered by the diverse stakeholders to the policy dilemmas presented in this context are not analyzed here. They are comparatively studied in Bizberge and Segura (2020).

The study is based on different sources such as public documents, regulations (resolutions, decrees, etc.), declarations and recommendations from international organizations, articles from the mass and specialized press.

\section{FREEDOM OF EXPRESSION}

With regard to freedom of expression, three types of problems are identified: the spread of disinformation by companies and governments, the automatic censorship of social media platforms, and the promotion of self-censorship by governments.

\section{SPREAD OF Disinformation}

Tedros Adhanom Ghebreyesus, director general of the World Health Organization (WHO), warned about the risks of "infodemic" - the spread of disinformation about the pandemic - , and said that "the evolution of the coronavirus outbreak will depend on the extent to which the correct information is delivered to the people who need it" (Ghebreyesus \& NG, 2020, para. 11). The UN, the Organization of American States and the Organization for Security and Co-operation in Europe rapporteurs on freedom of expression, through both joint and separate statements, urged governments to promote and protect the access to, and free circulation of, information during the pandemic, and to provide accurate information on the nature of the threat posed by covid-19 (Comisión Interamericana de Derechos Humanos, 2020c; United Nations, 2020). They also entreated internet companies to address the problem of false information about the pandemic with reliable information (Comisión Interamericana de Derechos Humanos, 2020c; United Nations, 2020). In this regard, Unesco contributed with the creation of a Covid-19 Response Resource Center that includes materials on disinformation, freedom of expression, journalists' safety and interrelated human rights, access to information and knowledge, and digital technologies (Unesco, n.d.). In addition, it produced statements (for example, International Bioethics Committee \& World Commission on the Ethics of Scientific Knowledge and Technology, 2020) and policy documents (such as Posetti \& Bontcheva, 2020a, 2020b) that also address the use of digital technologies and disinformation.

Along the same lines, the Inter-American Commission on Human Rights published recommendations urging governments and companies to address the pandemic from a human rights perspective on freedom of expression on the internet, combat disinformation, and ensure access to public information, among others (Bizberge, 202Oa; Comisión Interamericana de Derechos Humanos, 2020a). The Pan American Health Organization also expressed its concern and provided material to combat disinformation about health risk (Organización Panamericana da la Salud, n.d.). 
Disinformation - understood as false, misleading or unverifiable information deliberately distributed to promote ignorance with certain interests (Comisión Interamericana de Derechos Humanos, 2019b) - is produced and circulated by mass media, journalists and communicators, political leaders, religious leaders, intellectuals and others who have influence on public opinion. Its spread through the social networks can be easy, net-like, instantaneous and massive, which is particularly problematic (Amnistía Internacional, 2018). Multiple pseudoscientific or anti-scientific, denialist and conspiratorial discourses as diverse as some astrological, warmongering, vegan or mystical ones have been spread about the new type of coronavirus. Examples of this at governmental level were the assertions of Brazilian president Jair Bolsonaro, who on March 24 defined the disease as "a little flu or a cold" ('Gripezinha ou resfriadinho' e outras 7 frases controversas de líderes mundiais sobre o coronavirus, 2020). Initially, the president of Mexico, Antonio Manuel López Obrador, also minimized the health threat and asked people, as he did on March 22, "not to stop going out" or take "exaggerated" measures ("Pese a coronavirus pide AMLO 'no dejar de salir' ni tomar medidas 'exageradas'”, 2020, paras. 1-2). However, the Mexican federal government later changed its position in accordance with the measures that some regional authorities were already adopting and followed the advice of specialists such as the undersecretary for Prevention and Health Promotion, Hugo López-Gatell. Thus, López-Gatell leads the daily press conferences broadcast simultaneously by all federal public media and by social media in which he provides profuse accurate information on the health emergency. In Argentina, unlike what has been said about Brazil, examples of disinformation appeared at the media level. Viviana Canosa, a well-known communicator, drank chlorine dioxide on TV. Ten days later, a 5-year old child died as a result of poisoning with that substance, which his parents gave to him to prevent covid-19. Canosa was reported for illegal practice of medicine.

In view of the claims regarding the spread of disinformation that put thousands of people's health around the world at risk, social media corporations were forced to take action. Twitter modified its content moderation policies and deleted tweets that go against health recommendations or encourage the use of harmful treatments ("Twitter adapta sus normas para atajar la desinformación y el contenido engañoso por el coronavirus", 2020). WhatsApp, in turn, limited the possibilities of forwarding messages to one at a time, which, according to the company, resulted in a $70 \%$ reduction in message forwarding (Agencia Europa Press, 2020).

Similarly, more than 90 social data verification organizations around the world have been working since January 2020 on a collaborative project coordinated by the International Fact-Checking Network to refute disinformation related to coronavirus. In Latin America, since April of 2020, 22 media from the region and Spain have joined forces in the "Latam Chequea" network, a collaborative project to verify information about coronavirus and fight the "infodemic" (Fundación Gabo, 2020). In addition, local data verification organizations such as Argentina's Chequeado also offer specific checks of information on covid-19 in each country. 
At the governmental level, the Argentine state news agency, Télam, launched the information-checking platform Confiar "to confront false information about coronavirus" (Télam lanza Confiar, una plataforma para enfrentar la información falsa sobre coronavírus, 2020). This constitutes an unprecedented experience of the use of a state managed platform for the verification of public discourse. In addition, a group of researchers of the Consejo Nacional de Investigaciones Científicas y Técnicas (National Research Council) has refuted more than 100 fake news about coronavirus in the "Ciencia Anti Fake News" (Science Anti Fake News) project (Consejo Nacional de Investigaciones Científicas y Técnicas, 2020). Besides, to combat disinformation, the Argentine and Mexican governments have published paid announcements on Google so that every time someone searches for anything related to covid-19, the first result will be the official information provided by each country's health agency. This implies large amounts of money for the platform, but it seems to be an effective way to provide reliable information to the population.

\section{Private Censorship}

During the global health crisis, the use of artificial intelligence by social networks shows renewed limitations to freedom of expression, since a large number of cases of content removal for alleged violations of their policies have been reported. Even though they have not been exactly prior censorship, the problem is the lack of transparency and accountability of these practices. One of the most known cases was that of Twitter's content removal of Brazilian president Jair Bolsonaro's messages where he challenged the WHO's recommendations related to covid-19 and discouraged isolation. Regardless of the value judgment on the content, what happened was a clear example of non-transparent practices for content moderation.

The rapporteurs on freedom of expression warned that this automatic and nontransparent censorship "may lead to the limitation of access to important information on public health and should only be carried out when the rules of necessity and proportionality are met" (Comisión Interamericana de Derechos Humanos, 2020c, para. 7) and the UN rapporteur stated that companies should avoid relying exclusively on automated moderation (United Nations, 2020). The Inter-American Commission on Human Rights (Comisión Interamericana de Derechos Humanos, 2020a) also recommended that companies guarantee access to content and avoid blocking media sites, platforms, or particular internet accounts.

Latin American organizations such as Intervozes of Brazil, Article 19 and Red en Defensa de los Derechos Digitales of Mexico, ADC (Asociación por los Derechos Civiles) of Argentina, Datos Protegidos of Chile and the regional Derechos Digitales, among others, have long demanded platform transparency and accountability through more or less formal regulatory mechanisms. Therefore, in this context, some of them such as the regional Observatorio Latinoamericano de Regulación de Medios y Convergencia and 
Fundación Karisma of Colombia have launched initiatives to document cases of blockades, content deletion or censorship of any kind during the advance of covid-19 (Rangel \& Martínez, 2020).

\section{Government Promotion of Self-Censorship}

On April 8, the Argentine minister of security, Sabina Frederic, announced that, in the context of pandemic and isolation, they were carrying out "cyber-patrolling" of information publicly available on social networks in order to monitor "the social mood" (Frederic habló de "ciberpatrullaje para medir humor social" $y$ desató otra polémica, 2020, para. 1). The announcement sparked a strong controversy. In addition, at least five people were reported to have been arrested in connection with their expressions on social networks just during April, as a result of this open source intelligence practice. As noted by numerous experts, international organizations such as the Inter-American Commission on Human Rights (Comisión Interamericana de Derechos Humanos, 2020b) and civic organizations such as the Iniciativa Ciudadana para el Control del Sistema de Inteligencia whose members are the Centro de Estudios Legales y Sociales, Fundación Vía Libre and the Instituto Latinoamericano de Seguridad y Democracia, this violates the presumption of innocence, the expectation of privacy for conversations, even those held in public, and turns the security forces into observers of public discourse (Centro de Estudios Legales y Sociales, 2020; Iniciativa Ciudadana para el Control del Sistema de Inteligencia, 2020). Therefore, it threatens freedom of expression, promotes self-censorship, reduces citizen participation and poses a problem for democracy.

Rulers have other ways to promote self-censorship. Reporters Without Borders has denounced that nine Latin American countries have not respected the right to freedom of expression during the covid-19 pandemic. In Brazil, president Jair Bolsonaro harassed the media (Reporteros Sin Fronteras, 2020b): backed by his family, some ministers and very active supporters on social media, he insults, discredits, stigmatizes and ridicules journalists who publish information that goes against the government's interests or their own, in order to undermine their credibility, create a common enemy, and avoid answering their questions (Reporteros Sin Fronteras, 2020a).

Summarizing, the data verification initiatives of civic organizations in the region and that of the Argentine state news agency, together with measures taken globally by social media platforms in order to reduce the risks of massive spread of disinformation, contribute to the access to accurate information on covid-19 and are therefore progressive in terms of human rights. On the other hand, the spread of disinformation registered in Brazil and initially in Mexico, the measures to promote self-censorship by the Argentine government, the Brazilian president's attacks on the press, and the excessive use of artificial intelligence for content moderation by global platforms are regressive. 


\section{ACCESS}

During the pandemic outbreak and the mandatory or recommended social isolation measures implemented by governments, two types of problems surfaced related to access: to connectivity and to content. Different actions were taken in order to deal with them.

\section{Access to Connectivity}

In Latin America, the use of the internet network increased on average by $25 \%$ during the first week of the pandemic (Bertolini, 2020) as a result of online learning, teleworking, personal communications, entertainment and e-commerce. The massive migration to teleworking strained the capacity of Wi-Fi routers due to the increase in work in the cloud (80\% increase in upload traffic) and videoconferences (Ookla/Speedtest, 2020, as cited in Agudelo et al., 2020). For example, in Chile and Ecuador there was a decrease in fixed broadband speed (-3\% and $-19.6 \%$, respectively) as well as an increase in broadband latency in different countries of the region such as Brazil (11.7\%), Chile (19\%), Ecuador (11.8\%) and Mexico (7.4\%; Ookla/Speedtest, 2020, as cited in Agudelo et al., 2020).

This set off the alarm for a potential "collapse" of the network. However, local experts, as well as global organizations such as Internet Society have argued that the internet infrastructure is resilient by design (Canabarro, 2020; Sullivan, 2020) and in normal conditions it adapts to peaks of high demand (for example, during the holiday season or during sports events such as the Olympic games). Nonetheless, the problem in the region is the last mile infrastructure and the existence of providers for end users who were not prepared to cope with the surge of bandwidth in the homes.

Besides, in Latin America, 33\% of the people lack connectivity (Comisión Económica para América Latina y el Caribe, 2020). In 11 countries in the region, between $60 \%$ and $85 \%$ of the homes do not have internet access (Comisión Económica para América Latina y el Caribe, 2020). These indicators show inequalities related to social class, age and location: at least half of the poor, rural, young and elderly people have no connectivity (Comisión Económica para América Latina y el Caribe, 2020). Between 50\% and 60\% of the homes in the two poorest quintiles, $77 \%$ of rural homes, $42 \%$ of people under 25 years old and $54 \%$ of people over 65 years old do not have internet access at home (Comisión Económica para América Latina y el Caribe, 2020).

The Inter-American Commission on Human Rights and its office of the special rapporteur on freedom of expression made a call to states to accelerate universal internet access policies during the covid-19 pandemic and recognized the actions taken so far in that respect because it is "crucial for the exercise of civil, political, economic, and cultural rights" (Comisión Interamericana de Derechos Humanos, 2020c, para. 2).

The Latin American governments have tried to mitigate the effects of the increasing traffic through various measures that include declaring telecommunications, information and communication technologies and even broadcasting to be essential services; 
video traffic management practices; and campaigns to promote the responsible use of networks by the population. According to Economic Commission for Latin America and the Caribbean (Comisión Económica para América Latina y el Caribe, 2020), the governments in the region have implemented measures to guarantee the accessibility, availability and affordability of telecommunication services, manage traffic to improve the efficiency of networks and allow free access to certain applications and websites, as well as measures related to consumer protection and preservation of service quality.

In Mexico, the continuity of telecommunication services has been guaranteed as part of the measures to prevent and mitigate the risks of the pandemic (ACUERDO por el que se establecen las medidas preventivas que se deberán implementar para la mitigación y control de los riesgos para la salud que implica la enfermedad por el virus SARS$\mathrm{CoV}_{2}, 2 \mathrm{O} 2 \mathrm{O}$ ), and the regulatory agency, Federal Institute of Communications, has urged federal, state and local authorities to maintain the effective provision of telecommunication and broadcasting services (Instituto Federal de Telecomunicaciones, 2020b).

Brazil established that telecommunication services and access to the internet are essential and must be guaranteed during the pandemic (Decreto $n^{\circ} 10.282,2020$ ). The Agência Nacional de Telecomunicações (2020a), the National Telecommunications Agency, signed agreements with different companies to "hold Brazil connected", which include continuity of services, priority attention to health and public security institutions, and to keep the population informed, among other issues. However, neither the government nor Agência Nacional de Telecomunicações has taken any measures to prohibit the disconnection of unpaid services, and the Federal Regional Court of Region 3 determined that it is possible to do so (Agência Nacional de Telecomunicações, 2020d; Valente, 2020).

In Argentina, fixed and mobile services, access to internet and pay TV (cable and satellite) have been declared "essential services" since the beginning of the pandemic and suspension and disconnection of these services for lack of payment has been banned for 180 days until August 31, 2020. Then, taking a step further, the president decreed that the internet, mobile phone services and pay TV are "public services in competition" and enabled the regulatory agency, Ente Nacional de Comunicaciones (National Telecommunications Agency), to regulate prices and control the quality of the services (Decreto $690 / 2020,2020)$. The decree also suspended the increase in the prices of services to end consumers until December 31, 2020. The official decision was met with adverse reactions from the opposition, telecom big players - who issued and op-ed on August 25 - as well as some coops and small and medium enterprises, who argued that it threatens competition and innovation and brings uncertainty to consumers. Instead, the academia and civil society organizations committed to communication rights have applauded the presidential decision (Bizberge, 2020b; Cámara Argentina de Internet, 2020; COLSECOR se expresó respecto al DNU 690, 2020; Federación Argentina de Carreras de Comunicación Social, 2020; Red de Carreras de Comunicácion Social y Periodismo, 2020).

To strengthen connectivity during the pandemic, the regulatory agency allocated $\$ 41.000 .000$ from the Universal Service Fund to increase the capacity of the fiber optic 
backbone network (Resolución 867/2020, 2020) in slums and underserved areas, and to broaden access to mobile communications so as to bring connectivity to road corridors.

Other measures have involved public and private agreements. In Argentina, Ente Nacional de Comunicaciones, the state-owned company Arsat and commercial private providers Claro, Dato, Movistar, and Telecom agreed to provide each other with cross support to face potential significant increases in traffic on their wholesale networks. Nevertheless, micro and small and medium enterprises retailers that provide home connection in most parts of the country acknowledge difficulties responding to the increasing traffic due to the obsolescence of networks, and have demanded palliative measures from the government.

Ente Nacional de Comunicaciones also agreed with Netflix and YouTube to lower the quality of its videos in the country so as to avoid overloading the networks. Similarly, in Brazil, Agência Nacional de Telecomunicações received a letter of commitment from broadcasters and internet audiovisual service providers stating that they are implementing voluntary technical measures to minimize the impact on the network caused by the use of digital services (Agência Nacional de Telecomunicações, 2020b).

In this scenario, organizations that promote community internet networks in rural or marginal urban areas, like Altermundi and Atalaya Sur in Argentina, Redes por la Diversidad, la Equidad y la Sustentabilidad A.C. and Rizhomática in México, and Artigo 19 in Brazil, have repositioned their proposal as an option to extend connectivity in areas that are not reached by private or state providers, or are served with low quality and/or high prices (Prato et al., 2020; Roca, 2020). The Association for Progressive Communications recommends that "rapid improvement of community networks" policies is needed to respond to the pandemic (Asociación para el Progreso de las Comunicaciones, 2020, para. 11). In Argentina, for instance, Altermundi - which already has an agreement for a free point to point link with the Córdoba National University network operation center - reiterated its request to the provincial electric power company for establishing a link to its fiber network so as to optimize the quality of service in this context.

\section{Zero-Rating Content}

Measures were adopted to promote free access to educational content, health information and entertainment. The Inter-American Commission on Human Rights and its office of the special rapporteur for freedom of expression recognized these measures and pointed that even "if sustained over time could be problematic in terms of pluralism, [however they appear] to be adequate and proportional during an emergency such as that of the covid-19" (Inter-American Commission on Human Rights, 2020, para. 11).

In Argentina, the Ministry of Education and national universities agreed with private providers (Claro, Movistar, and Telefónica) to grant free access to content hosted on domains edu.ar. Besides, public universities offered connectivity grants to low-income students so that they could pay for mobile data or loan devices, and the Ministry of Education offered teachers credits for the purchase of computers through the Banco de la 
Nación Argentina (Argentine National Bank). It also implemented the program "Seguimos Educando" (We Keep Teaching), which has a website to access different educational resources as well as radio and TV programs from public and community stations. It also distributes printed study guides with classes for different educational levels. At the same time, the National Ministry of Education launched the federal plan "Juana Manso", which focuses on granting teachers and students from elementary and high school levels access to virtual classrooms and to a repository of free and open content, providing connectivity to schools, as well as equipment (computers) and training for teachers.

To promote free access to official content about coronavirus, the Mexican Instituto Federal de Telecomunicaciones (Federal Institute of Telecommunications) made an agreement with mobile operators AT\&T, Telefónica, Telcel (América Móvil), and Alban Redes (Instituto Federal de Telecomunicaciones, 2020a). Likewise, in Brazil, the use of the app Coronavírus-SUS to monitor the pandemic does not consume data.

Private operators allow free data access to government applications and the main communication media in Brazil (Agudelo et al., 2020). For instance, Claro, the main provider of mobile and pay TV services in the country, voluntarily took measures to provide free wi-fi in public places and airports, grant its pre-paid costumers free access to messages from the Ministry of Health for 1 hour, free access to TV signals for limited time, and free access to books, music and games for its clients. Other companies such as Vivo, Tim and Oi adopted similar measures. In Argentina, Cablevision gave all its customers free access to its video on demand app Flow.

Around the world, libraries, publishers, academic publications, museums and ecommerce platforms of cultural products opened its access - at different levels and timeframes - to part of its content related to the pandemic, culture, and entertainment. Likewise, some websites that offered materials released from copyright, out-of-print or hard-to-find publications but recent material as well, increased their activity, sparking heated debates in Argentina on copyright and intellectual property (Fundación Vía Libre, 2020). At a global level, Creative Commons made a call on March 25, 2020, for open access policies to be accelerated around the world in the context of the pandemic, stating that it is necessary to have rapid, unrestricted access in the most open terms possible to scientific research and educational materials on covid-19 (Red en Defensa de los Derechos Digitales, 2020a). More than a dozen companies, Amazon, Facebook, Microsoft, and IBM, among others, announced their adherence to the "Open Covid" initiative promoted by Creative Commons and have released their patents in order to facilitate research on covid-19 (Red en Defensa de los Derechos Digitales, 2020b). These measures imply progress, but they are of exceptional nature, and it is likely that companies will return to their practices of restricted and paid access to content once the health crisis has been overcome. However, they have put the cultural rights of access to content up for debate.

In summary, public policies in association with those of private providers' of guaranteeing access to connectivity and to health, educational and entertainment contents online have proved to be progressive in terms of human rights in the three countries 
studied. However, there are important differences between the countries in terms of degree, depth and scope. Argentina adopted a more interventionist approach than Mexico and Brazil, with a strong presence of the state both in ruling and allocating public funds. In Brazil, the adoption of rules to promote access faced limitations in its implementation when the judiciary ended up allowing the cutting off of services. In the three countries, there were public and private initiatives for cooperation that not only included continuity of access to the internet but also zero-rating practices for accessing different types of content. If this type of measures is usually considered a threat to net neutrality, in this exceptional context they are considered appropriate and proportionate.

\section{PRIVACY}

As SARS-CoV-2 advances in Latin America, there are discussions concerning the use of personal data for surveillance and population control in order to monitor the transmission of the virus, as well as the appropriation and sale of personal data for commercial purposes.

\section{State SuRVeillance}

In Latin America, as in other counties of the world, governments have adopted measures to use information from mobile phones and its apps to control the spread of SARS-CoV-2, despite the fact that fundamental individual rights are not always protected to a reasonable extent. Besides, the covid-apps usefulness and effectiveness are not proved. In addition, there are doubts as to whether they are absolutely necessary or cannot be replaced by less intrusive methodologies. Moreover, it is not clear whether these measures can be discontinued once the exceptional situation has been overcome.

According to the Economic Commission for Latin America and the Caribbean (Comisión Económica para América Latina y el Caribe, 2020), the apps implemented nationally by the governments of Argentina (Cuidar), Brazil (Coronavírus-SUS) and Mexico (COVID-19MX) include features such as information to prevent contagions, news, information on health premises, and auto-test systems. The Mexican and Brazilian apps also share official data of the covid-19 situation in the country. Distinctive features of the Argentina app are the provision of instructions during quarantine and the permission to circulate.

The national application implemented in Argentina for self-assessment of covid-19 symptoms and, at the beginning of the pandemic, for monitoring compliance with the mandatory quarantine for those who arrived in the country from abroad, includes geolocation with the express informed consent of the user. Besides, the WhatsApp number provided by the Argentine government to receive inquiries and facilitate self-examination allows at the same time identifying telephone numbers and, in this way, people who are requesting that information (Lara, 2020). The updated version of the app allows the user to obtain permission to circulate for authorized activities. Digital rights organizations 
argued that the purpose of the application was not clear, since it generated uncertainty as to what other functions it might include in the future. At first, the code was private. Therefore, concerns were raised on how the use of personal data, especially geolocation, could endanger the privacy of the population (Muro, 2020). The government was receptive to critics and implemented adjustments on the app such as opening the source code, making geolocation optional and restricting the storing of the data to the duration of the pandemic (Coronavirus en Argentina: El Gobierno modificará la app CuidAR para reforzar la protección de los datos personales, 2020).

The Brazilian corona-app received criticism from civil society organizations that raised issues of transparency and security, and to a lesser extent, of consent (Gomes et al., 2020). President Bolsonaro has rescinded an agreement between telecommunications companies and the Ministry of Science, Technology, Innovation and Communication that was intended to provide information on mobile phones related to geographic location and mobilization. The decision was more connected with a reckless policy regarding the pandemic than to the protection of personal data. However, state authorities have the power to implement them (Lara, 2020).

This case shows that governments in the region face significant opposition when launching and maintaining massive digital surveillance apparatuses to contain the pandemic, not because of a firm official commitment to protecting personal data or to balancing public health objectives and democratic rights, but because of poor reach and limited effectiveness of digital and mobile technologies as well as state problems of governance and the provision of health services in the region (Segura \& Waisbord, 2019; Waisbord \& Segura, 2021)

Government administrations are not monolithic. Once the Brazilian press released information on projects for the collection and digital processing of mobility data of users of telecommunications services for health and security purposes, Agência Nacional de Telecomunicações (2020c) warned that this must be subject to current legislation and, above all, to the Federal Constitution. It pointed out as well that "the balance of protection between health and privacy is at the highest level of our normative hierarchy"; and that even in the current crisis, "reconciling both legal rights" is possible (Agência Nacional de Telecomunicações, 2020c, para. 3). The agency also argued that, since individual rights can be affected, the "proportionality" of the judgment, the cost-benefit relationship, the possibility of less invasive alternatives and individual consensus must be observed (Agência Nacional de Telecomunicações, 2020c, para. 3).

The culture of privacy protection, although growing, is still in its early stages in Brazil. In a scenario in which there is specific awareness of the subject on the part of individuals, it is the public power's duty to protect them in dimensions whose consequences can be much more permanent than the current crisis. (Agência Nacional de Telecomunicações, 2020c, para. 3)

Finally, Brazil - like most of the countries in the region, except Peru and Uruguay - did not implement the application that informs of possible contacts with infected people (Comisión Económica para América Latina y el Caribe, 2020). 
In this scenario, civic and academic initiatives offered their expertise. Besides, surveillance technology companies such as the NSO Group, however, saw a huge business opportunity. As was recently revealed in Mexico and Guatemala, the company used these technologies in the region to spy on journalists and activists (Rodriguez, 2018).

The rapporteurs for freedom of expression of the UN, the Organization of American States and the European Union asked governments to limit the use of surveillance technologies to track the spread of the virus. The Inter-American Commission on Human Rights (Comisión Interamericana de Derechos Humanos, 2020a) also recommended guaranteeing the right to privacy and the processing of personal data of patients and individuals who are examined during the pandemic.

In addition, the coalition of Latin American civil society organizations Al Sur and more than 100 organizations around the world urged governments to ensure that the development of digital technologies that use sensitive and location information in this context respects human rights. Such organizations also alerted about the possible irreversibility of measures implemented during the pandemic. The regional organization Derechos Digitales warns that the use of these technologies poses countless doubts:

how the information will be anonymized and aggregated so as not to identify individuals, who has access to the information, how it will be used (and in contrast to what other data), for how long and under what conditions it will be stored, etc... (while) its usefulness in relation to its penetration levels, meanwhile, are still a mystery. (Lara, 2020, para. 4)

Nonetheless, these digital technologies have a weak impact. Initially, specialists set that, to provide significant results, they should be adopted by, at least, $60 \%$ of the population (Cerrato et al., 2020). Until October 2020, 7 months after the pandemic has reached Latin America, the most popular digital applications of covid-19 in the region were the Brazilian and the Argentine ones, downloaded by more than 5,000,000 people, followed by the Colombian one downloaded by more than 3,000,000 people (Pasquali, 2020). Then, the apps from Peru, Mexico and Ecuador were downloaded by less than 1,000,000 people, and the others, by less than only 100,000 people (Pasquali, 2020). If we compare the downloads of these apps and the number of cell phones available in each country, the Argentine app is the most used by just $14 \%$ of cell phones owners, followed by the Colombian (5\%), and the Brazilian Coronavírus-SUS (4\%; Segura, 2020). Given that the penetration of these apps is not significant, its usefulness to control the pandemic is extremely limited (Segura, 2020).

\section{Trade of Personal Data}

The appropriation and sale of personal data for commercial purposes was also debated when the sale of data to Facebook carried out globally by the Zoom videoconferencing platform became known. Zoom was forced to give explanations because of public opinion pressure. Even if the harvesting of personal data as a result of increased virtual 
activity during the pandemic is a topic unto itself, the aim of this mention is just to make a reference to the context where civil society organizations of a Latin American country proposed an option to avoid the big platforms. In this scenario, social organizations that develop free software in Argentina partnered with the national state and installed Jitsi in the servers of the state-owned company Arsat to offer a free option, free of charge, without information leakage and backed by sufficient infrastructure capacity to support many simultaneous massive video-conferences for health institutions. Besides, several national universities adopted Jitsi for teaching and meetings online.

Summarizing, the unusual expansion of digital technologies for state surveillance and control through digital technologies to monitor the possible transmission of the virus would imply a significant regression in human rights that would be difficult to reverse in the post-pandemic scenario. Even though this regressive impact was limited because they have not been massively adopted, it clearly increases the amount of information that states have of their populations in centralized databases. Another human rights regression happens with the appropriation of personal data and its commercial sale by e-learning and teleworking platforms.

\section{Conclusions}

There were three types of digital rights under discussion during the pandemic and isolation in Latin America: access, privacy, and freedom of expression. Each one of these rights is affected by various types of problems caused by governments and/or by the internet and telecommunications companies: connectivity, patient geolocation, content removal, disinformation.

Public policies have included some regressive measures such as the official spread of disinformation, the promotion of self-censorship, and surveillance, but it also introduced some progressive measures, sometimes in association with civil society organizations, such as those aimed at guaranteeing access to connectivity and to online content (zero rating offers).

As we stated in Bizberge and Segura (2020), the different approach in each country is associated with the political orientation of its rulers, as well as the targeted public policies implemented for covid-19 and the existing power relations between the players involved: highly concentrated internet service providers and internet intermediaries; governments with little margins to attain balance between politics and economy, and a civil society that, despite being heterogeneous, manages to make its public voice heard in the debates.

Internet companies developed regressive strategies globally which, in certain cases - such as the spread of fake news, automatic censorship, or the sale of personal data from videoconferencing platforms -, they had to reverse, offer explanations or provide alternative solutions.

In relation to connectivity companies (internet service providers), they formed alliances with governments and adopted courses of action that contributed to the expansion of rights with temporary measures such as enabling access to zero rating content 
and the establishment of minimum service plans to maintain the conditions of access to information services and communication.

The civil society in each country tried to influence governments so that they would promote progressive solutions and, in some cases, it was able to offer alternative solutions, such as data verification, community internet networks, free software videoconferencing platforms, and open access agreements.

In situations of risk, exceptional measures are taken that can set adverse precedents, such as surveillance practices, public and private censorship. However, they also bring the opportunity to build progressive, viable and sustainable alternatives such as exceptional zero rating practices to guarantee access to tele-education, community internet solutions, or free software.

The crisis is also fertile ground for debating digital rights from a multistakeholder approach that considers inputs from all the players involved with a much broader social scope. It is up to social activism, private companies' cooperation, and state decisions to transform this adverse situation into a window of opportunity to guarantee and exercise more and better rights.

\section{English revision: Silvia Villegas}

\section{REFERENCES}

ACUERDO por el que se establecen las medidas preventivas que se deberán implementar para la mitigación y control de los riesgos para la salud que implica la enfermedad por el virus SARS-CoV2 (COVID-19), Diario Oficial de la Federación, Secretaría de Gobernación (2020). https://www.dof.gob.mx/nota_ detalle.php?codigo $=5590339 \&$ fecha $=24 / 03 / 2020$

Agencia Europa Press. (2020, April 27). ¿Funcionó el nuevo límite de reenvío en WhatsApp a una vez por chat? Los números dicen que sí. La Voz del Interior. https://www.lavoz.com.ar/tecnologia/ funciono-nuevo-limite-de-reenvio-en-whatsapp-a-una-vez-por-chat-numeros-dicen-que-si

Agência Nacional de Telecomunicações. (2020a, March 20). Anatel e setor de telecom firmam compromisso público para manter Brasil conectado. Governo do Brasil. https://www.gov.br/anatel/pt-br/assuntos/ noticias/anatel-e-setor-de-telecom-firmam-compromisso-publico-para-manter-brasil-conectado

Agência Nacional de Telecomunicações. (2020b, April 7). Radiodifusores e empresas de streaming reafirmam seu compromisso com os serviços. Governo do Brasil. https://www.gov.br/anatel/pt-br/assuntos/noticias/ radiodifusores-e-empresas-de-streaming-reafirmam-seu-compromisso-com-os-servicos

Agência Nacional de Telecomunicações. (2020c, April 15). Posicionamento da Anatel a respeito da utilização de rastreamento de usuários de telecomunicações no âmbito de medidas no combate à pandemia de covid-19. Governo do Brasil. https://www.gov.br/anatel/pt-br/assuntos/noticias/posicionamento-da-anatel-arespeito-da-utilizacao-de-rastreamento-de-usuarios-de-telecomunicacoes-no-ambito-de-medidas-nocombate-a-pandemia-de-covid-19

Agência Nacional de Telecomunicações. (2020d, April 16). Decisão do TRF3 suspende liminar que proibia cortes e Anatel emite comunicado às prestadoras de telefonia fixa e móvel. Governo do Brasil. https://www.gov.

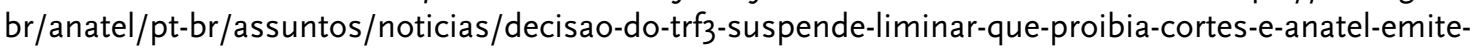
comunicado-as-prestadoras-de-telefonia-fixa-e-movel 
Agudelo, M., Chomali, E., Suniaga, J., Núñez, G., Jordán, V., Rojas, F., Negrete, J. F., Bravo, J., Bertolini, P., Katz. R., Callorda, F., \& Jung, J. (2020). Las oportunidades de la digitalización en América Latina frente al covid-19. Corporación Andina de Fomento; Naciones Unidas. https://scioteca.caf.com/bitstream/ handle/123456789/1541/Las_oportunidades_de_la_digitalizacion_en_America_Latina_frente_al_ Covid-19.pdf? sequence $=5 \&$ isAllowed $=y$

American Convention on Human Rights, November 22, 1969, https://www.cidh.oas.org/basicos/english/ basic3.american\%2oconvention.htm

Amnistía Internacional. (2018). El debate público limitado: Trolling y agresiones a la libertad de expresión de periodistas $y$ defensores de DDHH en Twitter Argentina. https://amnistia.org.ar/wp-content/uploads/ delightful-downloads/2018/03/online-pre1.pdf

Asociación para el Progreso de las Comunicaciones. (2020, April 14). Más cerca que nunca: Qué hacer para que nuestros movimientos se mantengan conectados e inclusivos - Respuesta de la Asociación para el Progreso de las Comunicaciones frente a la pandemia de covid-19. https://www.apc.org/es/pubs/ mas-cerca-que-nunca-que-hacer-para-que-nuestros-movimientos-se-mantengan-conectados-e

Bertolini, P. (2020, March 23). El tráfico de datos registró incrementos de más del 25\% en promedio en la última semana en América Latina. DPL News. https://digitalpolicylaw.com/el-trafico-de-datos-registroincrementos-de-mas-del-25-en-promedio-en-la-ultima-semana-en-america-latina/

Bizberge, A. (2020a, April 16). Medios y covid-19 en América Latina. OBSERVACOM. https://www.observacom. org/medios-y-covid-19-en-america-latina/

Bizberge, A. (2020b, August 26). Declaran servicio público en competencia a la telefonía móvil, acceso a internet $\gamma$ TV paga en Argentina. OBSERVACOM. https://www.observacom.org/ declaran-servicio-publico-en-competencia-a-la-telefonia-movil-acceso-a-internet-y-tv-paga-en-argentina/

Bizberge, A., \& Segura, M. S. (2020). Los derechos digitales durante la pandemia covid-19 en Argentina, Brasil y México. Revista de Comunicación, 19(2), 61-85. https://doi.org/10.26441/RC19.2-2020-A4

Cámara Argentina de Internet. (2020, August 24). Declarar a la conectividad como servicio público solo traerá mayor concentración y menor competencia en el sector. https://www.cabase.org.ar/declarar-a-laconectividad-como-servicio-publico-solo-traera-mayor-concentracion-y-menor-competencia-en-elsector/

Canabarro, D. (2020, May 2). ¿Qué podemos aprender sobre la resiliencia de internet en el contexto de covid-19? OBSERVACOM. https://www.observacom.org/ que-podemos-aprender-sobre-la-resiliencia-de-internet-en-el-contexto-de-covid-19/

Castells, M. (2009). Comunicación y poder. Alianza Editorial.

Centro de Estudios Legales y Sociales. (2020). Sobre el "Proyecto de protocolo de ciberpatrullaje". https://www. cels.org.ar/web/wp-content/uploads/2020/04/CELS-sobre-protocolo-ciberpatrullaje.pdf

Centro Estratégico Latinoamericano de Geopolítica. (2020, April 11). Geografía política del coronavirus en América Latina. https://www.celag.org/geografia-politica-de-coronavirus-en-america-latina/

Cerrato, I., D 'Agostino, M., Galdon Clavell, G., Pombo, C., \& Tejerina, L. (2020, December). Tecnologías digitales para la notificación de exposición en época de pandemia. Inter-American Development Bank. https://publications.iadb.org/publications/spanish/document/Tecnologias-digitales-para-lanotificacion-de-exposicion-en-epoca-de-pandemia.pdf

Collier, D. (1993). The comparative method. In A. W. Finifter (Ed.), Political science: The state of the discipline II (pp. 105-119). American Political Science Association. 
COLSECOR se expresó respecto al DNU 690. (2020, August 28). COLSECOR Noticias. http://colsecornoticias. com.ar/index.php/noticias/9405-colsecor-se-expreso-respecto-al-dnu-69o

Comisión Económica para América Latina y el Caribe. (2020). Universalizar el acceso a las tecnologías digitales para enfrentar los efectos del COVID-19. Naciones Unidas. https://repositorio.cepal.org/bitstream/ handle/11362/45938/4/S2000550_es.pdf

Comisión Interamericana de Derechos Humanos. (2008). Lineamientos para la elaboración de indicadores de progreso en materia de derechos económicos, sociales y culturales. OAS. https://www.oas.org/es/cidh/ docs/pdfs/lineamientos.pdf

Comisión Interamericana de Derechos Humanos. (2011). Declaración conjunta sobre libertad de expresión e internet. http://www.oas.org/es/cidh/expresion/showarticle.asp?artID=849\&/ID=2

Comisión Interamericana de Derechos Humanos. (2013). Informe anual de la Comisión Interamericana de Derechos Humanos 2013. Volumen II. Informe de la relatoría especial para la libertad de expresión. OAS. http://www.oas.org/es/cidh/docs/anual/2013/informes/LE2013-esp.pdf

Comisión Interamericana de Derechos Humanos. (2017). Estándares para una internet libre, abierta e incluyente. Relatoría especial para la libertad de expresión de la Comisión Interamericana de Derechos Humanos. OAS. http://www.oas.org/es/cidh/expresion/docs/publicaciones/internet_2016_esp.pdf

Comisión Interamericana de Derechos Humanos. (2019a). Declaración conjunta del vigésimo aniversario: Desafios para la libertad de expresión en la próxima década. http://www.oas.org/es/cidh/expresion/ showarticle.asp?art $|\mathrm{D}=1146 \&| I \mathrm{D}=2$

Comisión Interamericana de Derechos Humanos. (2019b). Guía para garantizar la libertad de expresión frente a la desinformación deliberada en contextos electorales. OAS. http://www.oas.org/es/cidh/expresion/ publicaciones/Guia_Desinformacion_VF.pdf

Comisión Interamericana de Derechos Humanos. (2020a). Pandemia y derechos humanos en las Américas. OAS. http://www.oas.org/es/cidh/decisiones/pdf/Resolucion-1-2O-es.pdf

Comisión Interamericana de Derechos Humanos. (2020b, April 18). CIDH y su RELE expresan preocupación por las restricciones a la libertad de expresión y el acceso a la información en la respuesta de Estados a la pandemia del COVID-19 [Press release]. http://www.oas.org/es/cidh/expresion/showarticle. asp?art $|\mathrm{D}=1173 \&| \mid \mathrm{D}=2$

Comisión Interamericana de Derechos Humanos. (2020c, March 19). Covid-19: Los gobiernos deben promover y proteger el acceso y la libre circulación de la información durante la pandemia - Expertos internacionales [Press realese]. http://www.oas.org/es/cidh/expresion/showarticle.asp?artID=1170\&IID=2

Consejo Nacional de Investigaciones Científicas y Técnicas. (2020, July 27). El equipo de científicos y científicas del CONICET que ya desmintió más de cien fake news sobre coronavirus [Press release]. https://www. conicet.gov.ar/el-equipo-de-cientificos-y-cientificas-del-conicet-que-ya-desmintio-mas-de-cien-fake-newssobre-coronavirus/

Coronavirus: El mapa interactivo que muestra las medidas o distintos tipos de cuarentena que adoptaron los países de América Latina. (2020, April 27). BBC News Mundo. https://www.bbc.com/mundo/ noticias-america-latina-52248497

Coronavirus en Argentina: El Gobierno modificará la app CuidAR para reforzar la protección de los datos personales. (2020, May 16). Infobae. https://www.infobae.com/politica/2020/05/16/coronavirus-enargentina-el-gobierno-modificara-la-app-cuidar-para-reforzar-la-proteccion-de-los-datos-personales/

Decreto 690/2020, Boletín Oficial de la República Argentina, $\int 1$ (2020). https://www.boletinoficial.gob.ar/ detalleAviso/primera/233932/20200822 
Decreto $\mathrm{n}^{\circ}$ 10.282, de 20 de março de 2020, Diário Oficial da União, 『1-Extra (2020). https://www.in.gov.br/ en/web/dou/-/republicacao-249098206

Estatuto de la Comisión Interamericana de Derechos Humanos, October, 1979, http://www.oas.org/es/cidh/ mandato/Basicos/estatutoCIDH.asp

Federación Argentina de Carreras de Comunicación Social. (2020). Declaración en relación al DNU 690. https://www.fcedu.uner.edu.ar/wp-content/uploads/2020/08/Declaraci\%C3\%B3n-DNU-69o_ FADECCOS.pdf

Frederic habló de "ciberpatrullaje para medir humor social" $y$ desató otra polémica. (2020, April 8). Perfil. https:// www.perfil.com/noticias/actualidad/sabina-frederic-ciberpatrullaje-redes-sociales-medir-humor-socialno-me-van-a-callar.phtml

Freedman, D. (2008). The politics of media policy. Polity Press.

Fundación Gabo. (2020, April 2). Más de 100 stios para verificar desinformación sobre el covid-19. https:// fundaciongabo.org/es/noticias/mas-de-100-sitios-para-verificar-desinformacion-sobre-el-covid-19

Fundación Vía Libre. (2020, May 15). El derecho de autor ante la emergencia y el aislamiento. http://srv.vialibre. org.ar/boletines/resumen_semanal/mayo20201/

George, A., \& Bennett, A. (2004). Case studies and theory development in the social sciences. MIT Press.

Chebreyesus, T., \& NG, A. (2020, February 18). Desinformación frente a medicina: Hagamos frente a la Ginfodemiai. El País. https://elpais.com/sociedad/2020/02/18/actualidad/1582053544_191857.html

Gomes, A., Luciano, M, Fragoso, N., \& Pavarin, V. (2020, April 30). Covid-19: Apps do governo e seus riscos à privacidade. InternetLab. https://www.internetlab.org.br/pt/privacidade-e-vigilancia/ covid-19-apps-do-governo-e-seus-riscos/

'Gripezinha ou resfriadinho' e outras 7 frases controversas de líderes mundiais sobre o coronavirus. (2020, April 7). BBC News Mundo. https://www.bbc.com/portuguese/internacional-52205918

Iniciativa Ciudadana para el Control del Sistema de Inteligencia. (2020, April 16). La cibervigilancia masiva está prohibida. Fundación Vía Libre. https://www.vialibre.org.ar/2020/04/16/ comunicado-iccsi-la-cibervigilancia-masiva-esta-prohibida/

Instituto Federal de Telecomunicaciones. (2020a, March 20). Operadores de telecomunicaciones móviles ofrecerán acceso gratuito a contenidos oficiales sobre coronavirus [Press release]. http://www.ift.org.mx/ sites/default/files/comunicacion-y-medios/comunicados-ift/comunicado26ift_l.pdf

Instituto Federal de Telecomunicaciones. (2020b, April 2). Exhorto a las autoridades federales, estatales $y$ municipales para que, en el ámbito de sus atribuciones, coadyuven a la continuidad en la prestación de los servicios de telecomunicaciones y radiodifusión ante la contingencia covid-19 [Press release]. http://www.ift. org.mx/sites/default/files/comunicacion-y-medios/comunicados-ift//comunicadoexhortovf.pdf

Inter-American Commission on Human Rights. (2020, August 31). States of the region must accelerate universal internet access policies during the covid-19 pandemic and adopt differentiated measures to incorporate groups in vulnerable situations [Press release]. http://www.oas.org/en/iachr/expression/ showarticle.asp? art $|\mathrm{D}=1182 \&| I \mathrm{D}=1$

International Bioethics Committee, \& World Commission on the Ethics of Scientific Knowledge and Technology. (2020). Statement on covid-19: Ethical considerations from a global perspective. Unesco. https://unesdoc.unesco.org/ark:/48223/pfoooo373115

International Commission for the Study of Communication Problems. (1980). Many voices, one world. Unesco. 
Iosifidis, P. (2011). Global media and communication policy. Palgrave Macmillan.

Jenkins, H. (2006). Convergence culture: Where old and new media collide. New York University Press.

Katzenbach, C. (2012). Technologies as institutions: Rethinking the role of technology in media governance constellations. In N. Just, \& M. Puppis (Eds), Trends in communication policy research: New theories, methods and subjects (pp. 117-138). Intellect.

Lara, C. (2020, May 1). La pandemia de covid-19 y la pulsión por la vigilancia estatal. Derechos Digitales. https://www.derechosdigitales.org/14411/la-pandemia-de-covid-19-y-la-pulsion-por-la-vigilancia-estatal/

Lessig, L. (2004). Free culture. How big media uses technology and the law to lock down culture and control creativity. Penguin Press.

Lijphart, A. (1971). Comparative politics and the comparative method. The American Political Science Review, 65(3), 682-693. https://doi.org/10.2307/1955513

McQuail, D. (2010). La regulación de los medios [Working paper]. University of Leicester.

Milan, S., \& van der Velden, L. (2016). The alternative epistemologies of data activism. Digital Culture and Society, 2(2), 57-74. https://doi.org/10.14361/dcs-2016-0205

Muro, V. (2020, May 11). App CuidAR: Los expertos piden cambios y más control sobre el destino de los datos. La Nación. https://www.lanacion.com.ar/tecnologia/ app-cuidar-expertos-reclaman-cambios-mas-controles-nid2364104

Organización Panamericana da la Salud. (n.d.). Covid-19: Communication documents. https://www.paho.org/ es/covid-19-materiales-comunicacion

Organización para la Cooperación y el Desarrollo Económicos, Banco de Desarrollo de América Latina, Comisión Económica para América Latina y el Caribe, \& Unión Europea. (2019). Perspectivas económicas de América Latina 2019: Desarrollo en transición. OCDE. https://www.cepal.org/sites/default/files/ publication/files/44525/S1900182_es.pdf

Oszlak, O., \& O’Donnell, G. (1976). Estado y políticas estatales en América Latina: Hacia una estrategia de investigación [Documento Cedes; $(4), 1976]$. CEDES. https://repositorio.cedes.org/ handle/123456789/3332

Pasquali, M. (2020, September 24). Las apps de movilidad, aliadas en la lucha contra el coronavirus en Latinoamérica. Statista. https://es.statista.com/grafico/23026/ apps-de-covid-19-mas-descargadas-en-latinoamerica/

Pese a coronavirus pide AMLO 'no dejar de salir' ni tomar medidas 'exageradas'. (2020, March 22). El Universal. https://www.eluniversal.com.mx/nacion/ coronavirus-pide-amlo-no-dejar-de-salir-ni-tomar-medidas-exageradas

Piovani, J. I., \& Krawczyk, R. (2017). Los estudios comparativos: Algunas notas históricas, epistemológicas y metodológicas. Educação e Realidade, 42(3), 821-840. https://doi.org/10.1590/2175-623667609

Posetti, J., \& Bontcheva, K. (2020a). DISINFODEMIC: Deciphering covid-19 disinformation. Unesco. https:// en.unesco.org/sites/default/files/disinfodemic_deciphering_covid19_disinformation.pdf

Posetti, J., \& Bontcheva, K. (2020b). DISINFODEMIC: Dissecting responses to covid-19 disinformation. Unesco. https://en.unesco.org/sites/default/files/disinfodemic_dissecting_responses_covid19_disinformation. pdf 
Prato, A. V., Weckesser, C., \& Segura, M. S. (2020). AlterMundi y la primera red comunitaria de Internet cien por ciento LibreRouter y extendida durante la pandemia de covid-19. Centro de Investigaciones de la Facultad de Filosofía y Humanidades, Universidad Nacional de Córdoba. http://democratizarcomunicacion.fcc. unc.edu.ar/informe-redes-comunitarias-de-internet/

Protocol of San Salvador, November 17, 1988, https://www.oas.org/juridico/english/sigs/a-52.html

Ragin, C. (2007). La construcción de la investigación social (M. S. Ravina, Trans.). Siglo del Hombre Editores. (Original work published 1994)

Rangel, V., \& Martínez, A. (2020, April 25). Pandemia, censura y control a la libertad de expresión en internet. Fundación Karisma. https://web.karisma.org.co/ pandemia-censura-y-control-a-la-libertad-de-expresion-en-internet/

Red de Carreras de Comunicácion Social y Periodismo. (2020). Declaración de Redcom ante el DNU G9o. https://www.redcomargentina.com.ar/declaracion-de-redcom-ante-el-dnu-69o/

Red en Defensa de los Derechos Digitales. (2020a, March 25). Creative Commons llama a reforzar el acceso abierto durante la emergencia sanitaria mundial. https://r3d.mx/2020/03/25/ creative-commons-Ilama-a-reforzar-el-acceso-abierto-ante-la-emergencia-sanitaria-mundial/

Red en Defensa de los Derechos Digitales. (2020b, April 27). Empresas de tecnología liberan patentes para el combate al covid-19. https://r3d.mx/2020/04/27/ gigantes-de-tecnologia-se-suman-al-compromiso-covid-abierto/

Reporteros Sin Fronteras. (2020a, April 16). Análisis trimestral de Brasil. Cómo el presidente Jair Bolsonaro, intenta acallar metódicamente a la prensa crítica. https://rsf.org/es/noticias/ analisis-trimestral-de-brasil-como-el-presidente-jair-bolsonaro-intenta-acallar-metodicamente-la

Reporteros Sin Fronteras. (2020b, June 29). Casi la mitad de países miembros de la ONU han dejado de respetar la libertad de prensa durante la pandemia. https://rsf.org/es/noticias/ casi-la-mitad-de-paises-miembros-de-la-onu-han-dejado-de-respetar-la-libertad-de-prensa-durante-la

Resolución 867/2020, Boletín Oficial de la República Argentina, \ 1 (2020). https://www.boletinoficial.gob.ar/ detalleAviso/primera/233934/20200822

Roca, R. (2020, April 2). En tiempos de crisis todas las comunidades necesitan estar conectadas. Internet Society. https://www.internetsociety.org/es/blog/2020/04/ en-tiempos-de-crisis-todas-las-comunidades-necesitan-estar-conectadas/

Rodriguez, K. (2018, December 30). Where governments hack their own people and people fight back: 2018 in review. Electronic Frontier Foundation. https://www.eff.org/es/deeplinks/2018/12/ where-government-hack-their-own-people-and-people-fight-back-latin-american

Schiffrin, A. (2017). Introduction. In A. Schiffrin (Ed.), In the service of power: Media capture and the threat to democracy (pp. 1-8). CIMA. https://www.cima.ned.org/wp-content/uploads/2017/08/ CIMA_MediaCaptureBook_Fr.pdf

Segura, M. S. (2020, November 12-13). Pandemic surveillance apps and privacy in Latin America [Paper presentation]. Pandemic Surveillance, Privacy, Security and Data Ethics Virtual Conference, Pennsylvania, United States.

Segura, M. S., \& Waisbord, S. (2016). Media Movements. Civil society and media policy reform in Latin America. Zedbooks.

Segura, M. S., \& Waisbord, S. (2019). Between data capitalism and data activism. Television Q New Media, 20(4), 1-8. https://doi.org/10.1177\%2F1527476419834519 
Sorj, B. (2010). Usos, abusos y desafios de la sociedad civil en América Latina. Siglo XXI.

Sullivan, A. (2020, April 8). Desafortunado experimento natural muestra que Internet funciona. Internet Society. https://www.internetsociety.org/es/blog/2020/04/ desafortunado-experimento-natural-muestra-que-internet-funciona/

Télam lanza Confiar, una plataforma para enfrentar la información falsa sobre coronavirus. (2020, April 6). Télam. https://www.telam.com.ar/notas/202004/448644-plataforma-confiar-telam-coronavirus.html

Twitter adapta sus normas para atajar la desinformación y el contenido engañoso por el coronavirus (2020, April 22). El Diario. https://www.eldiario.es/tecnologia/Twitter-desinformacion-contenido-enganosocoronavirus_O_1019449141.html\#click=https://t.co/xAays6Aciz

Unesco. (n.d.). Resource center of responses to covid-19. https://en.unesco.org/covid19/ communicationinformationresponse/mediasupport

Unesco. (2019). Tendencias mundiales en libertad de expresión y desarrollo de los medios: informe regional para América Latina y el Caribe 2017/2018. https://unesdoc.unesco.org/ark:/48223/pfoo00366564?posInSet=1 \&queryld=59e6c7af-19c1-4a6b-9619-e88ocdfaf785

United Nations. (2018). Report of the Special Rapporteur on the promotion and protection of the right to freedom of opinion and expression. https://freedex.org/wp-content/blogs.dir/2015/files/2018/05/G1809672.pdf

United Nations. (2020). Disease pandemics and the freedom of opinion and expression. Report of the Special Rapporteur on the promotion and protection of the right to freedom of opinion and expression. https:// freedex.org/wp-content/blogs.dir/2015/files/2020/04/A_HRC_44_49_AdvanceEditedVersion.pdf

Universal Declaration of Human Rights, December 10, 1948, https://www.un.org/en/about-us/ universal-declaration-of-human-rights

Valente, J. (2020, April 16). Justiça permite corte de serviços de telecomunicações de inadimplentes. Agência Brasil. https://agenciabrasil.ebc.com.br/justica/noticia/2020-04/ justica-permite-corte-de-servicos-de-telecomunicacoes-de-inadimplentes

Waisbord, S., \& Segura, M. S. (2021). Covid-19 pandemic and biopolitics in Latin America. In S. Milan, E. Treré, \& S. Masiero (Eds.), Covid-19 from the margins (pp. 29-32). University of Amsterdam. https:// networkcultures.org/wp-content/uploads/2021/02/Covid19FromTheMargins.pdf

Wu, T. (2003). Network neutrality, broadband discrimination. Journal of Telecommunications and High Technology Law, 1(2), 141-179. https://doi.org/10.2139/ssrn.388863

Zuboff, S. (2019). The age of surveillance capitalism. Public Affairs.

\section{BiograpHicAl Notes}

María Soledad Segura is professor at Faculty of Social Sciences and Faculty of Communication Sciences of National University of Córdoba, and researcher at Consejo Nacional de Investigaciones Científicas y Técnicas National (Council for Scientific and Technical Research; Conicet). She holds a PhD in social sciences, a master in contemporary communication and culture, and a degree in social communication. She published seven books - among them: De la Resistencia a la Incidencia. Sociedad Civil y Derecho a la Comunicación en la Argentina (From Resistance to Incidence. Civil Society and Commnuication 
Rights in Argentina; Ediciones UNGS, 2018) - and more than 100 papers, book chapters and opinion columns in the press.

ORCID: https://orcid.org/o0oo-0003-1847-942X

Email: maria.soledad.segura@unc.edu.ar

Address: Av. Valparaíso S/N, Córdoba Capital, X5000, Córdoba, Argentina

Ana Bizberge is professor at Faculty of Social Sciences, Institute of Latin American and Caribbean Studies (IEALC) of University of Buenos Aires. She is the head of the Master in Cultural Industries at National University of Quilmes and professor at School of Humanities of Universidad Nacional de San Martín and Torcuato Di Tella University. She holds a PhD in social sciences from University of Buenos Aires, a master in cultural industries from National University of Quilmes and a bachelor in communication science at University of Buenos Aires. Her most recent book is Convergencia Digital $y$ Políticas de Comunicación en Argentina, Brasil y México (2000-2017) (Digital Convergence and Communication Policies in Argentina, Brazil and Mexico; El Colectivo, 2020).

ORCID: https://orcid.org/oooo-0001-8267-4700

Email: anabizberge@gmail.com

Address: Santiago del Estero 1029, CABA, C1075AAU, Argentina

\section{Submitted: 15/09/2020 | Accepted: 15/01/2021}

This work is licensed under a Creative Commons Attribution-NonCommercial 4. o International License. 